\title{
Parotid Fluid Cortisol and Cortisone
}

\author{
Fred H. Katz and Ira L. Shannon \\ From the Department of Medicine, Loyola University Stritch School of Medicine, \\ Hines, Illinois 60141 and the Section of Experimental Dentistry, U. S. Air \\ Force School of Aerospace Medicine, Brooks Air Force Base, Texas 78235
}

\begin{abstract}
A в S T RAC T Parotid fluid corticosteroids, substantially comprised of cortisol and cortisone, were previously demonstrated to rise to far greater levels $4 \mathrm{hr}$ after administration of ACTH than they did in the third trimester of pregnancy, although the plasma total corticosteroid concentrations were similar in these two states. It was therefore suggested that only nonproteinbound corticosteroid gains access to parotid fluid. In the present study parotid fluid cortisol and cortisone and plasma dialyzable cortisol concentrations have been measured in normal men before and $2 \mathrm{hr}$ after $40 \mathrm{U}$ $\mathrm{ACTH}$, and, in another group, before and after 10 days of diethystilbestrol ( $5 \mathrm{mg}$ daily). Total plasma cortisol rose from a mean of 6.3 to $17.9 \mu \mathrm{g} / 100 \mathrm{ml}$ after ACTH and from 14.6 to $39.4 \mathrm{mg} / 100 \mathrm{ml}$ after the estrogen. However parotid fluid cortisol plus cortisone rose from 0.8 to $2.6 \mu \mathrm{g} / 100 \mathrm{ml}$ after ACTH and to only 2.2 after estrogen. This rise resembled that of the plasma dialyzable cortisol (control 0.4, ACTH 1.8, estrogen $1.2 \mu \mathrm{g} /$ $100 \mathrm{ml}$ ) rather than the increase in total plasma cortisol which was over twice as high after estrogen as after ACTH. Thus parotid fluid corticosteroids seem to be a good measure of nonprotein-bound corticosteroid, the cortisol available to the cell. The total amount of cortisol plus cortisone excreted is approximately constant, independent of parotid fluid flow rate. Cortisone exceeds cortisol in parotid fluid in the basal state, but after ACTH the situation is reversed.
\end{abstract}

\section{INTRODUCTION}

The concentration of 17-hydroxycorticosteroids in parotid fluid, as measured by the Porter-Silber reaction,

This work was published in part as an abstract in the J. Clin. Invest. 1966. 45: 1031, and presented in part at the 3rd International Congress of Endocrinology, Mexico City, Mexico, 30 June-5 July 1968.

Dr. Shannon's present address is Oral Physiology Research Laboratory, Veterans Administration Hospital, 2002 Holcombe Blvd., Houston, Tex. 77301.

Received for publication 23 September 1968 and in revised form 30 December 1968. parallels that of plasma after the administration of $\mathrm{ACTH}$ (1). Parotid fluid-Porter-Silber chromogens are also a useful index to adrenocortical suppression by dexamethasone $^{1}$ (2) and for the diagnosis of Cushing's syndrome (3). During pregnancy, despite a two- to threefold increase in plasma 17-hydroxycorticosteroids, the parotid fluid corticosteroids rose only minimally though significantly (4). Following ACTH treatment, when plasma corticosteroids were similar to the values found in pregnant women, the parotid fluid corticoids rose to values several times the base line. Because most of the increased plasma 17-hydroxycorticosteroids in pregnancy are protein-bound, whereas the acute increase following ACTH represents more nonprotein-bound steroid, it was suggested that mainly nonprotein-bound corticosteroid gains access to parotid fluid. To test this hypothesis we have investigated the parotid fluid concentration of cortisol and cortisone, the major corticosteroids previously found in this fluid, and compared it with plasma levels of nonprotein-bound cortisol under a number of physiologic conditions. The effect of parotid fluid flow rate and of time of collection were also investigated.

\section{METHODS}

Parotid fluid was collected with a modified Carlson-Crittenden device (5). Except in the flow rate experiment, salivary flow was stimulated by sucking a sour lemon or grape candy. All subjects were healthy Basic Airmen, aged 17-22, who had recently passed a military induction physical examination; they were studied in the postobsorptive state. All parotid fluid samples were obtained between 7 and 9 a.m. unless otherwise indicated. The fluid was immediately frozen and preserved in this state during shipping until thawed for steroid analysis. Blood was drawn into heparinized syringes and the cells separated from the plasma within $15 \mathrm{~min}$. The supernatant plasma was also frozen until the time of analysis.

Cortisol and cortisone in parotid fluid and cortisol in

\footnotetext{
${ }^{1}$ The following trivial names and abbreviations are used: Dexamethasone, $9 \alpha$-fluoro-16 $\alpha$-methyl-11,17,21-trihydroxypregn-1,4-diene-3,20-dione; PPO, diphenyloxazole; POPOP, 1,4-bis [2-(5-phenyloxazolyl)]benzene; CBG, corticosteroidbinding globulin.
} 
plasma were measured either by a double-isotope derivative technique or, more recently, by the competitive proteinbinding (CPB) analysis of Murphy (6). Both methods gave approximately the same results. A pool of samples of parotid fluid collected at 6 a.m. on several days from five normal subjects gave the following results (in $\mu \mathrm{g} / 100 \mathrm{ml}$ ) for triplicate determinations: double isotope, cortisol, 1.15, $1.23,1.35$; cortisone $1.56,1.66,1.71$; CPB assay, cortisol $1.17,1.29,1.42$; cortisone $1.62,1.73,1.42$. Duplicates by either technique differed from their mean by an average of 7.6 $\pm 3.0 \%$ (SD) of that mean. Recovery of added cortisol and cortisone ranged from 92 to $106 \%$.

Double-isotope derivative technique. Depending on the steroid being measured, either radioactive cortisol alone (for plasma) or radioactive cortisol and radioactive cortisone (for parotid fluid) were dried from ethyl alcohol solutions under a stream of air at $37^{\circ} \mathrm{C}$ in an extraction tube, in quantities of $6.4 \mathrm{~m} \mu \mathrm{g}$ ( $880 \mathrm{dpm}$ ) each. $5 \mathrm{ml}$ of parotid fluid or $1 \mathrm{ml}$ of plasma with $4 \mathrm{ml}$ of distilled water in duplicate was added to each tube and extracted with $10-15 \mathrm{ml}$ of methylene chloride or chloroform. A blank tube containing $5 \mathrm{ml}$ of distilled water was also run with each batch. After aspiration of the aqueous layer, the extract was washed with $3 \mathrm{ml}$ of $0.1 \times \mathrm{NaOH}$ and $3 \mathrm{ml}$ of distilled water. The extract was then dried and concentrated at the bottom of a conical test tube.

The steroids in the extracts of the biological fluids were dissolved in $10 \mu \mathrm{l}$ of dried pyridine stored over $\mathrm{BaO}$ and then acetylated by the addition of $5 \mu 1$ of freshly redistilled (7) acetic- ${ }^{3} \mathrm{H}$ anhydride $(50 \mu \mathrm{c} / \mu \mathrm{M})$. At the same time 50 $\mu \mathrm{g}$ of authentic cortisol was subjected to the same acetylation procedure. After $15-18 \mathrm{hr}$ at room temperature in the dark the reaction was stopped by the addition of $1 \mathrm{ml}$ of $25 \%$ ethyl alcohol. The steroid acetates were extracted into $10 \mathrm{ml}$ of methylene chloride. Following a wash with $1 \mathrm{ml}$ of water, the extracts were dried and $30 \mu \mathrm{g}$ each of authentic cortisol- and cortisone-21-acetates or cortisol acetate alone were added. Since final quantitation depended only on the relative recovery of steroid $-{ }^{14} \mathrm{C}$ that had been acetylated with tritium-labeled acetic anhydride prior to this step, and the quantitation of tritium in the final product, the addition of nonradioactive steroid acetate carrier at this stage did not affect the final result. Thin-layer chromatography was then performed with the following solvent systems consecutively: (a) methylene chloride-ethanol $96: 4$ (8); (b) methylene chloride-cyclohexanone-water $75: 25: 0.5$ (8) ; (c) acetonebenzene $33: 66(9)$.

After localization of the acetates on the chromatograms by ultraviolet light absorption $(254 \mathrm{~m} \mu)$ of the carrier steroid acetates, the spots were eluted with methyl alcohol by the use of zone extractors (10). System $a$ effectively separated cortisol acetate from cortisone acetate. After chromatography in system $b$, the dried eluate was dissolved in $1 \mathrm{ml}$ of water and extracted with $10 \mathrm{ml}$ of methylene chloride which in turn was washed once with $1 \mathrm{ml}$ of water, in order to remove nonspecific excess tritium. After chromatography in system $c$, the samples were chromatographed for a last time in system $a$. The eluates from the last chromatography were dried in a liquid scintillation counting vial and $10 \mathrm{ml}$ of a toluene solution containing $3 \%$ PPO and $0.01 \%$ POPOP was added for counting. An aliquot of the authentic cortisol that had been acetylated with the tritiated acetic anhydride was also counted at the same time, and another aliquot quantitated by the Porter-Silber reaction (11) to determine the precise molar specific activity of the acetic anhydride. The steroid recovered at the end of the procedure could then be quantitated by the tritium counts in the acetate and this corrected for the recovery of steroid $-{ }^{14} \mathrm{C}$. Finally the weight of the steroid- ${ }^{14} \mathrm{C}$ added at the beginning of the procedure was subtracted to obtain the actual quantity of steroid present in the biological fluid. The usual recovery by this method was between 25 and $40 \%$. In experiments in which no nonradioactive carrier was added and the steroids were located by radioisotope-scanning of the thin-layer chromatograms, similar recoveries of ${ }^{14} \mathrm{C}$ were found.

Competitive protein-binding analysis. For CPB analysis, extracts of the biological fluids were prepared in exactly the same way as for the acetylation in the double-isotope derivative assay, except that $2.5 \mathrm{ml}$ of parotid fluid in duplicate and $0.25 \mathrm{ml}$ of plasma in duplicate were used instead of the larger quantities. The dried extracts were chromatographed on $3 \mathrm{MM}$ Whatman filter paper in the B-5 system of Bush (12). The cortisol and cortisone areas were located on the chromatograms by the migration rate of authentic steroids on adjacent limbs, detected by staining with blue tetrazolium. The unknown samples were eluted (13) with ethyl acetate: methanol $1: 1$, dried, and dissolved in $2.0 \mathrm{ml}$ of ethyl acetate. A $0.8 \mathrm{ml}$ aliquot of the ethyl acetate solution was dried in a $13 \times 100$ tube for CPB analysis and another similar aliquot dried in a counting vial for determination of recovery. Recovery was usually $60-70 \%$ of theory. The samples for CPB assay were dried under a stream of air and quantitated by the method described for the ultramicro determination of corticoids by Murphy (6). Our method utilized $0,3,6,9$, and $12 \mathrm{~m} \mu \mathrm{g}$ quantities of cortisol or cortisone for the standard curve, $2 \%$ rabbit plasma containing $4 \mu \mathrm{c}$ corticosterone $-1,2-^{8} \mathrm{H} / 100 \mathrm{ml}$ as the $\mathrm{CBG}$ solution, and $20 \mathrm{mg}$ Florosil as adsorbent. The affinity of rabbit CBG for cortisone is slightly greater than that for cortisol, as shown in Fig. 1. Duplicate determinations of radioactivity in standard curves always agreed to within less than $5 \%$ of their mean value. The results obtained in the $C P B$ assay were then corrected for recovery of steroid- $-{ }^{14} \mathrm{C}$. As in the doubleisotope method, the weight of the steroid $-{ }^{14} \mathrm{C}$ had to be subtracted from this result to obtain the original mass of steroid in the biological fluid extracted.

Plasma-free cortisol. The fraction of plasma cortisol that was nonprotein-bound was determined by equilibrium dialysis after Bush (14). $1 \mathrm{ml}$ of plasma was dialyzed in a Visking sac against $4.0 \mathrm{ml}$ of $0.9 \%$ sodium chloride for $6 \mathrm{hr}$ at $37^{\circ} \mathrm{C}$ in a calibrated tube in which $0.01 \mu \mathrm{c}(0.2 \mathrm{~m} \mu \mathrm{g})$ cortisol$1,2-{ }^{8} \mathrm{H}$ had been dried from ethanol solution. ${ }^{2}$ At the end of the dialysis procedure, the sac was removed from the outside solution, rinsed with distilled water and, after a small opening had been cut in the dialysis membrane, the entire sac and its contents were placed into an extraction tube in which $8800 \mathrm{dpm}$ cortisol-4- ${ }^{14} \mathrm{H}$ had been dried. The volume of the outside solution was observed and $3.0 \mathrm{ml}$ of it pipetted into another extraction tube in which $1760 \mathrm{dpm}$ cortisol- $4-{ }^{14} \mathrm{C}$ had been dried. The volume in all the extraction tubes was brought to about $5 \mathrm{ml}$ with water and the steroids extracted with $15 \mathrm{ml}$ of methylene chloride. The extracts were washed with $3 \mathrm{ml}$ of $0.1 \mathrm{~N} \mathrm{NaOH}$ and $3 \mathrm{ml}$ of distilled water, dried in a counting vial, and the toluene scintillation solution added. The volume of the outside solution averaged $3.8 \mathrm{ml}$ with a standard deviation of $0.05 \mathrm{ml}$ for 50 different sera dialyzed in duplicate. These average volume changes for the inside and outside solution were utilized for all calculations. The actual tritium found in each solution was corrected for losses of cortisol $-{ }^{14} \mathrm{C}$ during the extraction procedure. The fraction of cortisol that was bound was calculated by the

\footnotetext{
${ }^{2}$ Cortisol obtained through the courtesy of the Endocrinology Study Section, N.I.H.
} 
formula of Slaunwhite and Sandberg (15). The fraction that was dialyzable was then assumed to be 1 minus the fraction bound. The calculated recovery of tritium in inside and outside solutions together ranged from 87 to $112 \%$ with a mean of $98.1 \pm 4.8 \mathrm{SD}$. Duplicate determinations of the free cortisol fraction had an average difference of $6.6 \pm 5.4 \%$ (SD) of their mean. Dialysis equilibrium was obtained at $6 \mathrm{hr}$ as in the study of Bush. Since data obtained by this method do not necessarily correlate with true in vivo nonproteinbound cortisol, the results have been used mainly for comparative purposes.

All samples were counted in a model Mark I liquid scintillation spectrometer. ${ }^{8}$ Tritium was effectively excluded from the "1"C-channel" and, for CPB samples, "C was excluded from the tritium channel. All counting data were recorded by the liquid scintillation spectrometer on punch cards via an on-line keypunch and calculations were performed by an IBM 7094 digital computer utilizing special programs written for these experiments. Figs. 2-4 (below) were also generated by the computer utilizing an on-line cathode ray oscilloscope and a $35 \mathrm{~mm}$ camera. Standard statistical methods were used (16).

\section{RESULTS}

Blank of the method. A water blank was determined for each batch of samples. These averaged $-0.01 \pm 0.02$ (SD) $\mu \mathrm{g} / 100 \mathrm{ml}$ of parotid fluid for cortisol and 0.04 \pm 0.03 (SD) $\mu \mathrm{g} / 100 \mathrm{ml}$ for cortisone by either method. Preliminary experiments confirmed that multiple chromatographic purifications and several solvent partitions as well as use of freshly distilled tritium-labeled acetic anydride were necessary to obtain satisfactorily low water blanks for the double-isotope derivative technique (7). Unwashed 3MM Whatman chromatography paper was used for the isolation of cortisol or cortisone for CPB analysis because, contrary to other media such as silica gel and glass fiber paper, its chomatographic eluates gave satisfactory low blank values.

Morning values and effect of ACTH. A group of 25 normal subjects had base-line determinations performed between 7 and 8 a.m., 3-4 hr after arising, and then were given 40 units of $\mathrm{ACTH}$ gel intramuscularly.

${ }^{8}$ Nuclear-Chicago Corporation, Des Plaines, Ill.
Repeat determinations were performed $2 \mathrm{hr}$ later. The mean concentrations of parotid fluid cortisol plus cortisone as well as the mean concurrent concentrations of total and dialyzable cortisol in plasma before and after ACTH are listed as group A in Table I. ACTH treatment rsulted in a considerable increase in parotid fluid steroids $2 \mathrm{hr}$ after injection.

A comparison was made between the concentration of parotid fluid cortisol plus cortisone determined by the specific techniques and the concentration of 17-hydroxycorticosteroids determined on another aliquot of the same parotid fluid by the Porter-Silber reaction (1). As summarized in Table II, in all cases Porter-Silber chromogens exceeded the concentration of specific steroid and this excess was greater after ACTH than in the control state.

Effect of estrogen treatment. The concentration of cortisol and cortisone in parotid fluid in subjects given diethylstilbestrol, $5 \mathrm{mg} /$ day for 10 days, is shown in Table I (group B). These subjects lived near the laboratory and were tested shortly after arising. Data were obtained before estrogen therapy and before and $2 \mathrm{hr}$ after the intramuscular injection of $40 \mathrm{U} \mathrm{ACTH}$ gel on the last day of diethylstilbestrol. Estrogen treatment resulted in a small rise in parotid fluid cortisol plus cortisone (group B, Table I) as well as the expected considerable increase in plasma total cortisol. The increase in nonprotein-bound cortisol to a mean of 1.2 $\mu \mathrm{g} / 100 \mathrm{ml}$ was not significant $(P>0.2)$.

Relationship of parotid fluid steroids to free and total plasma cortisol. Table I gives the mean values for dialyzable plasma cortisol as well as those for total plasma cortisol and parotid fluid cortisol plus cortisone in the two groups in the control state, following ACTH, and on the last day of estrogen treatment. $2 \mathrm{hr}$ after ACTH injection in group A, mean total plasma cortisol had almost tripled from 6.3 to 17.9 $\mu \mathrm{g} / 100 \mathrm{ml}$. The group receiving diethylstilbestrol had more than twice the total plasma cortisol level of the ACTH group, 39.4 compared to $17.9 \mu \mathrm{g} / 100 \mathrm{ml}$. De-

TABLE I

Comparison of Plasma Total and Dialyzable Cortisol and Parotid Fluid Cortisone Plus Cortisol in Three Groups

\begin{tabular}{|c|c|c|c|c|c|c|c|}
\hline \multirow[b]{2}{*}{ Group } & \multirow[b]{2}{*}{$n$} & \multicolumn{2}{|c|}{ Plasma total cortisol } & \multicolumn{2}{|c|}{ Plasma dialyzable cortisol } & \multicolumn{2}{|c|}{$\begin{array}{l}\text { Parotid fluid cortisone } \\
\text { plus cortisol }\end{array}$} \\
\hline & & Mean & SD & Mean & SD & Mean & SD \\
\hline & & \multicolumn{6}{|c|}{$\mu \mathrm{g} / 100 \mathrm{ml}$} \\
\hline A, control & 25 & 6.3 & 2.4 & 0.37 & 0.23 & 0.81 & 0.34 \\
\hline A, АCTH & 25 & 17.9 & 3.6 & 1.84 & 0.53 & 2.62 & 0.61 \\
\hline B, control & 9 & 14.6 & 4.3 & 0.90 & 0.38 & 1.76 & 1.03 \\
\hline B, estrogen & 9 & 39.4 & 4.0 & 1.21 & 0.13 & 2.24 & 0.43 \\
\hline
\end{tabular}


TABLE II

Comparison of Parotid Fluid Porter-Silber Chromogens with Cortisol Plus Cortisone by Double-Isotope Derivative Technique

\begin{tabular}{|c|c|c|c|c|c|c|c|}
\hline \multirow[b]{2}{*}{ Treatment } & \multirow[b]{2}{*}{$n$} & \multicolumn{2}{|c|}{$\begin{array}{c}\text { A } \\
\text { Porter-Silber } \\
\text { chromogens }\end{array}$} & \multicolumn{2}{|c|}{$\begin{array}{c}\text { B } \\
\text { Cortisol plus } \\
\text { cortisone }\end{array}$} & \multicolumn{2}{|c|}{$A-B$} \\
\hline & & Mean & SD & Mean & SD & Mean & SD \\
\hline & & \multicolumn{6}{|c|}{$\mu \mathrm{g} / 100 \mathrm{ml}$} \\
\hline Control & 18 & 3.4 & 1.4 & 0.89 & 0.33 & 2.45 & 1.37 \\
\hline АCTH & 18 & 7.6 & 2.1 & 2.60 & 0.67 & 4.96 & 1.77 \\
\hline & & & & & & \multicolumn{2}{|c|}{$P<0.001$} \\
\hline
\end{tabular}

spite this doubling of total plasma cortisol concentration, free plasma cortisol was lower in the estrogen group (mean of $1.21 \mu \mathrm{g} / 100 \mathrm{ml}$ ) than the ACTH group $(1.84 \mu \mathrm{g} / 100 \mathrm{ml}$ mean $)$. Parotid fluid cortisone plus cortisol rose to a degree similar to that of plasma dialyzable cortisol rather than that of total plasma cortisol. Thus the control mean parotid fluid steroid value of $0.81 \mu \mathrm{g} / 100 \mathrm{ml}$ rose to $2.62 \mu \mathrm{g} / 100 \mathrm{ml}$ after ACTH and the control value of $1.76 \mu \mathrm{g} / 100 \mathrm{ml}$ rose to $2.24 \mu \mathrm{g} / 100$ $\mathrm{ml}$ after estrogen.

That there was high correlation between parotid fluid corticol plus cortisone and plasma dialyzable cortisol is shown in Fig. 2 which demonstrates the regression line for the relationship between these two parameters. The correlation coefficient for this relationship was $0.83(P<0.005)$. The correlation of parotid fluid cortisol plus cortisone with total plasma cortisol, however, was similar $(r=0.75, P<0.005)$.

It was noted that in most individuals an increased concentration of corticosteroids seen in plasma or parotid fluid after ACTH was associated with a diminished ratio between the parotid fluid steroids and free plasma cortisol. This negative correlation for control, and ACTH and estrogen treatment is shown in Fig. 3. The correlation coefficient is -0.39 with a $P$ value of 0.005 .

Comparison of parotid fluid cortisol and cortisone. In the base-line state the mean value of parotid fluid cortisol was $0.43 \mu \mathrm{g} / 100 \mathrm{ml}$ and that for parotid fluid cortisone, $0.60 \mu \mathrm{g} / 100 \mathrm{ml}$. Cortisone generally exceeded cortisol and this difference was statistically significant (Table III).

Following ACTH administration there was a considerable rise in both steroids in the parotid fluid, and cortisol now exceeded cortisone to a statistically significant degree (Table III).

Effect of flow rate. Flow rate of parotid fluid was varied in each of 16 normal subjects by varying the stimulus to salivation. The lowest flow rates were obtained with mint-flavored chewing gum, medium flow rates with sweet cherry candy, and the highest flow rates

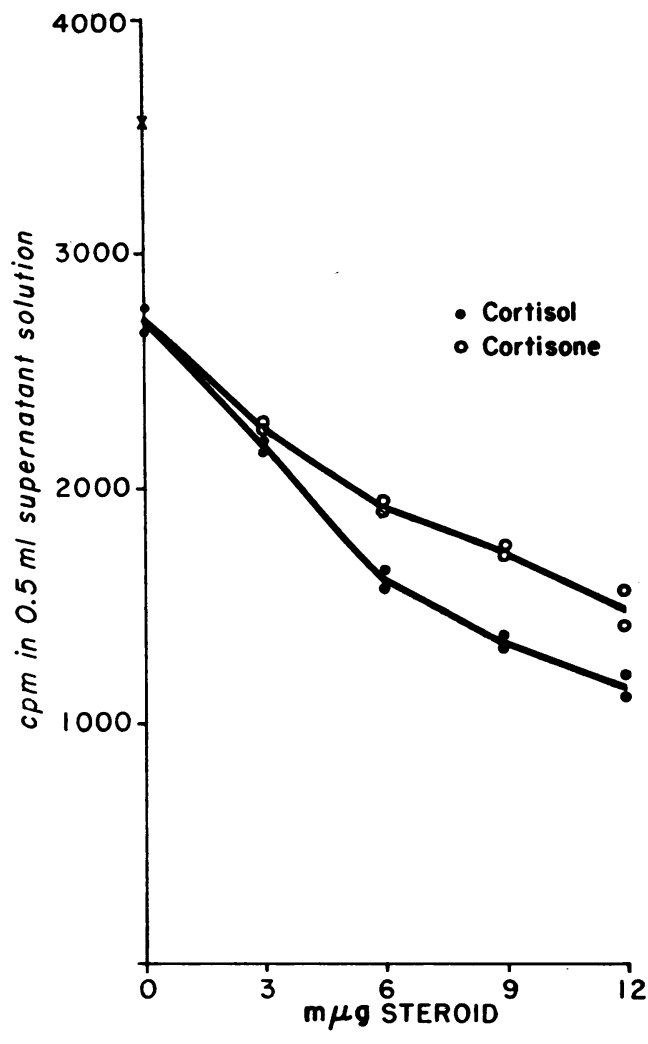

Figure 1 Typical standard curve for a concurrent CPB assay of cortisol and cortisone. The cross represents the radioactivity in $0.5 \mathrm{ml}$ of the rabbit $\mathrm{CBG}$ corticosterone- ${ }^{8} \mathrm{H}$ solution not equilibrated with Florosil.

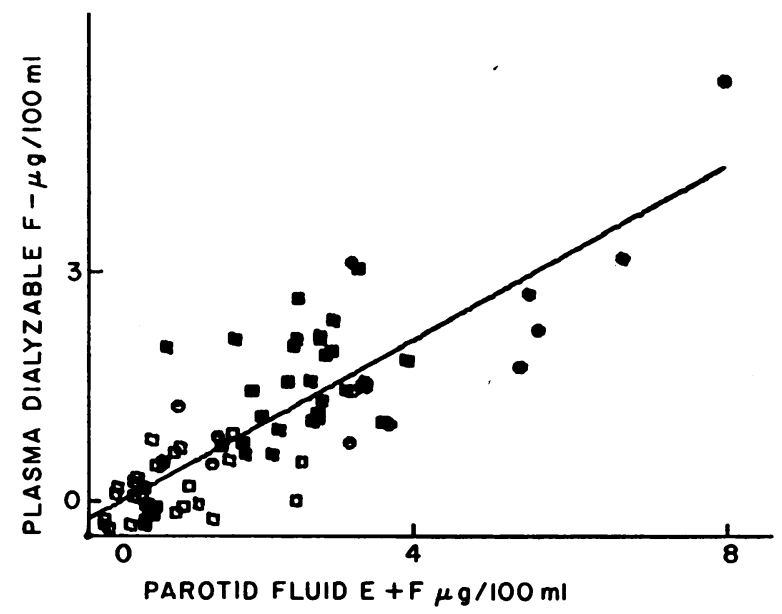

FIgURE 2 Correlation of plasma and parotid fluid steroids. There is a high positive correlation between the concentration of cortisol plus cortisone in parotid fluid and the concentration of dialyzable cortisol in plasma. $r=0.83 ; P<$ 0.005. (Open squares are controls, closed squares ACTH treatment, open circles estrogen, and closed circles estrogen plus ACTH. See text for details of treatment.) 
TABLE III

Comparison of Parotid Fluid Cortisone and Cortisol Concentrations

\begin{tabular}{|c|c|c|c|c|c|c|}
\hline \multirow[b]{2}{*}{ Group } & \multirow[b]{2}{*}{$n$} & \multicolumn{2}{|c|}{ Parotid fluid cortisone } & \multicolumn{2}{|c|}{ Parotid fluid cortisol } & \multirow[b]{2}{*}{$P<$} \\
\hline & & Range & Mean & Range & Mean & \\
\hline & & & & $\mu \mathrm{g} / 100 \mathrm{ml}$ & & \\
\hline Control* & 40 & $0.14-1.97$ & 0.60 & $0-1.48$ & 0.43 & 0.05 \\
\hline ACTH $\ddagger$ & 34 & $0.65-2.05$ & 1.21 & $0.69-2.67$ & 1.54 & 0.005 \\
\hline Estrogen & 9 & $0.43-2.28$ & 1.37 & $0.44-1.49$ & 0.87 & 0.20 \\
\hline Estrogen + ACTH & 6 & $1.14-3.43$ & 2.44 & $2.17-3.75$ & 3.38 & 0.10 \\
\hline
\end{tabular}

* Includes groups A and B in Table I as well as six additional subjects whose plasma cortisol was not measured.

$\ddagger$ Includes group $\mathrm{A}$ in Table $\mathrm{I}$ as well as nine additional subjects whose plasma cortisol was not measured.

with a sour grape candy. It was found that with increasing flow rate parotid fluid cortisol and cortisone concentrations diminish. At the lowest flow rate parotid fluid cortisol plus cortisone concentration could approach or exceed that found in concurrently collected plasma. The correlation coefficient of parotid fluid cortisol plus cortisone and flow rate was $-0.70(P<0.005)$. Fig. 4 shows that the excretion of steroid by the parotid gland remained relatively constant in each subject over the varying rates of flow.

Effect of dexamethasone. When $1 \mathrm{mg}$ of dexamethasone was administered orally at 7 a.m to normal subjects it was found that the diminution in parotid fluid cortisol plus cortisone at 11 a.m. was far greater than that found in untreated subjects. There was a mean reduction of $53.8 \%$ in parotid fluid cortisol plus cortisone concentration $4 \mathrm{hr}$ after dexamethasone, differing significantly $(P<0.01)$ from controls (mean reduction $10 \%$ ). Care was taken that the flow rate at 11 a.m. did not differ significantly from that at 7 a.m.

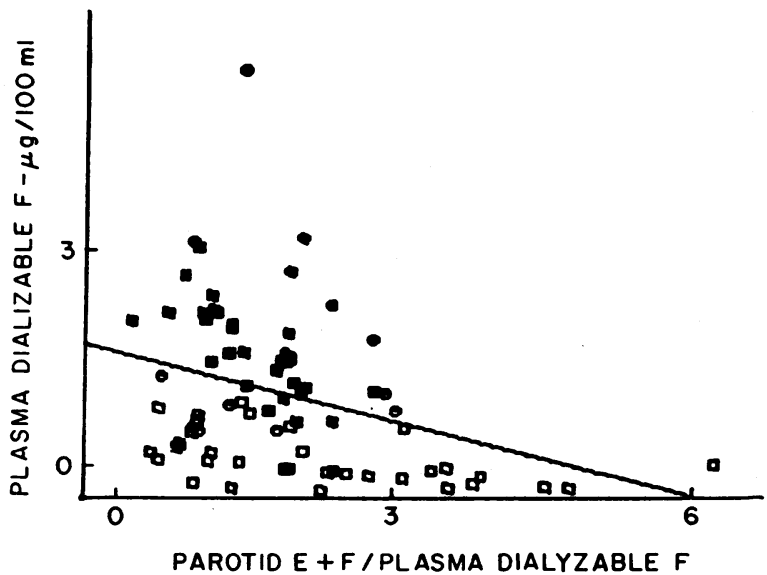

FigURE 3 Relationship of plasma-free cortisol to free cortisol that appears in saliva. As plasma dialyzable cortisol concentration rises, the fraction of this dialyzable cortisol found in parotid fluid diminishes. $r=0.39 ; P<0.005$. (Symbols same as Fig. 2.)
Diurnal variation in parotid fluid steroids. Five subjects had parotid fluid steroids measured at 6 a.m., noon, 6 p.m., and midnight. The data (Table IV) indicated that, like plasma cortisol, the concentrations of cortisol and cortisone in parotid fluid diminish as the day progresses, with general continuation of the pattern of cortisone exceeding cortisol. In two subjects steroids were completely undetectable in later specimens.

Cortisol binding by parotid fuid. Dialysis of tritiumlabeled cortisol between parotid fluid and normal saline was carried out to equilibrium by the same method used for plasma. The concentrations of radioactive cortisol on the two sides of the dialysis membrane were about equal whether the outside solution contained none, 100 or 200 $\mathrm{mg} / 100 \mathrm{ml}$ of crystalline human serum albumen. These

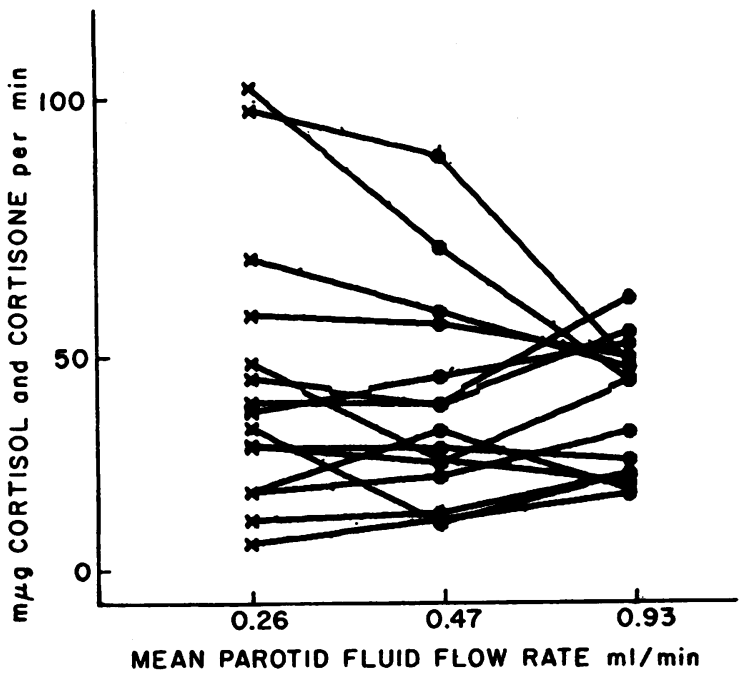

FIGURE 4 Excretion rate of parotid fluid corticosteroids. The amount of cortisol plus cortisone excreted per minute by one parotid gland remained relatively constant in 15 subjects in each of whom parotid fluid was collected at three different rates of flow. The excretion rates for each subject are joined by a straight line. 
TABLE IV

Diurnal Variation of Parotid Fluid Corticosteroids

\begin{tabular}{|c|c|c|c|}
\hline \multirow[b]{2}{*}{ Subject } & \multicolumn{3}{|c|}{ Steroid concentration* } \\
\hline & Cortisone & Cortisol & $\begin{array}{l}\text { Cortisol plus } \\
\text { cortisone }\end{array}$ \\
\hline & & $\mu \mathrm{g} / 100 \mathrm{ml}$ & \\
\hline \multirow[t]{4}{*}{1} & 1.26 & 1.35 & 2.61 \\
\hline & 0.72 & 0.86 & 1.58 \\
\hline & 0.25 & 0.06 & 0.31 \\
\hline & $\mathbf{0}$ & $\mathbf{0}$ & 0 \\
\hline \multirow[t]{4}{*}{2} & 1.34 & 0.99 & 2.33 \\
\hline & 0.70 & 0.19 & 0.89 \\
\hline & 0.48 & 0.23 & 0.71 \\
\hline & 0.27 & 0.29 & 0.58 \\
\hline \multirow[t]{4}{*}{3} & 1.33 & 1.01 & 2.34 \\
\hline & 0.56 & 0.44 & 1.00 \\
\hline & 0 & 0 & 0 \\
\hline & 0 & 0 & 0 \\
\hline \multirow[t]{4}{*}{4} & 0.90 & 0.74 & 1.64 \\
\hline & 0.54 & 0.21 & 0.75 \\
\hline & 0.62 & 0.22 & 0.84 \\
\hline & 0.50 & 0.29 & 0.79 \\
\hline \multirow[t]{4}{*}{5} & 0.81 & 0.28 & 1.09 \\
\hline & 0.46 & 0.29 & 0.75 \\
\hline & 0.51 & 0.27 & 0.78 \\
\hline & 0.39 & 0.25 & 0.64 \\
\hline
\end{tabular}

* Parotid fluid was obtained from each subject at 6 a.m., noon, 6 p.m., and midnight; steroid concentrations are listed in that order.

concentrations of serum albumin approximate the protein concentrations found in parotid fluid (17).

Cushing's syndrome. Parotid fluid corticosteroids were determined before and $2 \mathrm{hr}$ after $40 \mathrm{U}$ ACTH gel was given intramuscularly to a $37 \mathrm{yr}$ old woman with long standing Cushing's syndrome due to adrenal hyperplasia of hypothalamic pituitary origin, who subsequently underwent bilateral total adrenalectomy. Each adrenal gland weighed $22 \mathrm{~g}$. Morning base-line parotid fluid cortisol was 0.43 and cortisone $1.00 \mu \mathrm{g} / 100 \mathrm{ml}$, with a plasma cortisol concentration of $27.1 \mu \mathrm{g} / 100 \mathrm{ml} .2 \mathrm{hr}$ after the ACTH parotid fluid cortisol was 2.04 and cortisone $2.45 \mu \mathrm{g} / 100 \mathrm{ml}$. Plasma cortisol had risen to $42.1 \mu \mathrm{g} / 100 \mathrm{ml}$. The fraction-free cortisol was $8.7 \%$ base line and $12.6 \%$ after ACTH.

\section{DISCUSSION}

Although cortisone and cortisol were the only two Porter-Silber positive steroids identified in human parotid fluid in the previous study (4), the present quantitative analysis for these two specific steroids indicates that the sum of the cortisone plus cortisol is far less than the concentration of total Porter-Silber chromogens (Table II). In the previous study little radioactivity was found in parotid fluid after intravenous administration of radioactive cortisol other than that associated with cortisol and cortisone in ethyl acetate extracts of the parotid fluid. The Porter-Silber chromogens were measured in methylene chloride extracts of parotid fluid. This would exclude highly polar steroids and would suggest that any unknown Porter-Silber chromogens measured by the color reaction are less polar than cortisol and cortisone. These might for example be sulfates, acetates, or other esters of cortisol or cortisone. Steroid acetates have been identified in blood (18). Additional evidence that this Porter-Silber positive material is of adrenocortical origin in the present study is the greater excess of unknown steroid after ACTH (Table II). Further, more careful search for less polar cortisol metabolites in parotid fluid would therefore be warranted.

Since the plasma concentration of cortisone is generally less than $40 \%$ that of cortisol (19), it is assumed that much of the cortisone in the parotid fluid, which exceeds cortisol in the basal state, arises from the oxidation of cortisol from plasma by parotid tissue, as previously demonstrated in vitro (4). After ACTH the excess of cortisol over cortisone in parotid fluid may represent a flooding of this enzymatic mechanism by the sudden increase in the amount of cortisol presented to the gland by the plasma. It is possible that during estrogen treatment the mechanism adjusts gradually to the slowly increasing plasma cortisol.

The hypothesis that parotid fluid corticosteroids are more closely related to nonprotein-bound plasma cortisol than total plasma cortisol seems to have been confirmed by the finding that following estrogen, despite a mean plasma total cortisol level more than twice that found $2 \mathrm{hr}$ after intramuscular $\mathrm{ACTH}$, the parotid fluid cortisol plus cortisone was slightly less than that after ACTH, a relationship similar to that of the values for nonprotein-bound cortisol under these two experimental conditions. It may be noted that the sampling time of $2 \mathrm{hr}$ after intramuscular ACTH was selected because preliminary experiments showed that at this time the plasma level of cortisol was less than that after a week of estrogen therapy. In this context it has therefore been shown that the parotid fluid steroid changed like the plasma dialyzable cortisol rather than the plasma total cortisol concentration. Parotid fluid cortisol plus cortisone concentration thus represents a good measure of cortisol available to the cell since protein-bound steroid is apparently not physiologically active (20). In addition, parotid fluid corticosteroids appear to be a good measure

\footnotetext{
* This has been confirmed by unpublished studies in our own laboratory.
} 
(Table IV) of the diurnal variation in plasma cortisol and adrenocortical suppression with dexamethasone.

The ratio between parotid fluid cortisol plus cortisone and plasma dialyzable cortisol concentrations is not constant, however, (Fig. 3) as one would expect if parotid fluid were a mere filtrate of plasma corticosteroids. The mechanism of salivary secretion of other nonelectrolytes has been interpreted in similar terms (21). Parotid fluid appears to contain no corticosteroid-binding protein, as demonstrated by dialysis studies, thus making it unnecessary to consider this factor in parotid fluid corticosteroid excretion.

The lack of significant increase of plasma dialyzable cortisol after estrogen differs from other reports of an increase in nonprotein-bound corticosteroid in pregnancy or after estrogen treatment (22-24), but this may be due to the short period of treatment in this study.

When salivary flow is stimulated, the concentration of cortisol plus cortisone appears to vary inversely with flow rate resulting in an approximately constant excretion rate (Fig. 4). The mean minute excretion of cortisol plus cortisone was $40.7 \mathrm{~m} \mu \mathrm{g}$ for one parotid gland, as determined at mid-morning when plasma cortisol is perhaps at its median concentration (25). This would represent a daily excretion of $120 \mu \mathrm{g}$ by both parotid glands. Assuming that the parotid glands are unstimulated for $23 \mathrm{hr}$ a day, excrete an average volume of $0.08 \mathrm{ml} / \mathrm{min}^{5}$ per gland during that time, and that they secrete $0.75 \mathrm{ml} / \mathrm{min}$ during $1 \mathrm{hr}$ a day of stimulation, a total parotid fluid production of $300 \mathrm{ml} /$ day would be found in the average man. This represents about $2.75 \%$ of a day's output of gastrointestinal secretions (26). If the other gastrointestinal glands excrete corticosteroids at a similar rate, for which there is some evidence (27), this would represent an enteric secretion of 3.2 $\mathrm{mg}$ of cortisol metabolites daily, more than $10 \%$ of the average adrenal production rate (28).

\section{ACKNOWLEDGMENTS}

The work described in this paper could not have been completed without the faithful and meticulous technical assistance of Miss Janet Marie Cobb. Miss Judith Wiley and Mrs. Grace You Lin Wu assisted in some of the early technical work. Myron B. Lezak assisted in the development of the double-isotope derivative technique. The secretarial assistance of Mrs. Jane Kresler and Miss Synetra Williams is also gratefully acknowledged.

This research was supported by U. S. Air Force Contracts Nos. 41 (609)-2786 and 41609-67-C0008, and by General Research Support Grant funds from the U. S. Public Health Service to the Loyola University Stritch School of. Medicine.

\section{REFERENCES}

1. Shannon, I. L., J. R. Prigmore, R. A. Brooks, and R. P. Feller. 1959. The 17-hydroxycorticosteroids of parotid fluid, serum and urine following intramuscular adminis-

${ }^{5}$ Mean unstimulated flow rate in 15 subjects studied. tration of repository corticotropin. J. Clin. Endocrinol. Metab. 19: 1477.

2. Shannon, I. L., S. C. Beering, and R. L. Jenson. 1966. Dexamethasone suppression tests employing parotid fluid. J. Clin. Endocrinol. Metab. 26: 967.

3. Shannon, I. L., S. C. Beering, and F. H. Katz. 1966. Parotid fluid steroid responses to ACTH in surgically confirmed cases of Cushing's syndrome. J. Clin. Endocrinol. Metab. 26: 11.

4. Katz, F. H., and I. L. Shannon. 1964. Identification and significance of parotid fluid corticosteroids. Acta Endocrinol. 46: 393.

5. Shannon, I. L., J. R. Prigmore, and H. H. Chauncey. 1962. Modified Carlson-Crittenden device for the collection of parotid fluid. J. Dent. Res. 41: 778.

6. Murphy, B. E. P. 1966. Some studies of the proteinbinding of steroids and their application to the routine micro and ultramicromeasurements of various steroids in body fiuids by competitive protein-binding radioassay. J. Clin. Endocrinol. Metab. 27: 973.

7. Henderson, H. H., F. Crowley, and L. E. Gaudette. 1965. Purification of high specific activity acetic- $\mathrm{H}^{8}$ anhydride. Advan. Tracer Methodol. 2: 83.

8. Quesenberry, R. O., E. M. Donaldson, and F. Ungar. 1965. Descending and ascending chromatography of steroids using thin-layer chromatography sheets. Steroids. 6: 167.

9. Diab, I. M., and A. W. Gomoll. 1966. Color characterization of adrenal corticoids on thin-layer chromatograms. Steroids. 8: 109.

10. Matthews, J. S., A. L. Pereda V., and A. Aguilera P. 1962. Steroids CCXV. The quantitative analysis of steroids by thin-layer chromatography. J. Chromatogr. 9: 331 .

11. Frantz, A. G., F. H. Katz, and J. W. Jailer. 1961. $6 \beta$-Hydroxycortisol and other polar corticosteroids: measurement and significance in human urine. J. Clin. Endocrinol. Metab. $21: 1290$.

12. Bush, I. E. 1952. Methods of paper chromatography of steroids applicable to the study of steroids in mammalian blood and tissues. Biochem. J. 50: 372.

13. Frantz, A. G., D. A. Holub, and J. W. Jailer. 1960. Further evidence of a relative lack of C-21 hydroxylation in congenital adrenal hyperplasia. J. Clin. Invest. 39: 904.

14. Bush, I. E. 1957. Physicochemical state of cortisol in blood. In Ciba Foundation Colloquia on Endocrinology. Hormones Blood. 11: 263.

15. Slaunwhite, W. R., Jr., and A. A. Sandberg. 1959. Transcortin: a corticosteroid-binding protein of plasma. $J$. Clin. Invest. 38: 384.

16. Snedecor, G. W. 1956. Statistical Methods Applied to Experiments in Agriculture and Biology. Iowa State College Press, Ames. 5th edition.

17. Shannon, I. L., and J. R. Prigmore. 1960. The effect of flow rate on parotid fluid composition. USAF School of Aviation Medicine. Technical Report 60. 77.

18. Weichselbaum, T. E., and H. W. Margraf. 1960. Isolation and identification of adrenocortical steroids in human peripheral plasma. I. A naturally occurring $C_{21}$ steroid acetate (11-dehydrocorticosterone acetate) and "free" tetrahydrocortisone in normal plasma. J. Clin. Endocrinol. Metab. 20: 1341.

19. Ichikawa, Y. 1966. Metabolism of cortisol-4- $\mathrm{C}^{14}$ in patients with infectious and collagen diseases. Metabolism. 15: 613 .

20. Slaunwhite, W. R., Jr., G. N. Lockie, N. Back, and A. A. 
Sandberg. 1962. Inactivity in vivo of transcortin-bound cortisol. Science. 135: 1062.

21. Burgen, A. S. V., and N. G. Emmelin. 1961. Physiology of the Salivary Glands. Edward Arnold. London. 221

22. Doe, R. P., H. H. Zinneman, E. B. Flink, and R. A. Ulstrom. 1960. Significance of the concentration of nonprotein-bound plasma cortisol in normal subjects, Cushing's syndrome, pregnancy, and during estrogen therapy. J. Clin. Endocrinol. Metab. 20: 1484.

23. Plager, J. E., K. G. Schmidt, and W. J. Staubitz. 1964. Increased unbound cortisol in the plasma of estrogentreated subjects. J. Clin. Invest. $43: 1066$.

24. Doe, R. P., P. B. Dickinson, W. R. Swain, H. H. Zinneman, and U. S. Seal. 1967. Nonprotein-bound 17OHCS at 9 A.M. and 9 P.M. in normals, pregnancy, estrogen-treated females, and males with cancer of the prostate. Program, 49th Meeting of the Endocrine Society. Abstract No. 80.

25. Orth, D. N., D. P. Island, and G. W. Liddle. 1967. Experimental alteration of the circadian rhythm in plasma cortisol (17-OH-CS) concentration in man. J. Clin. Endocrinol. Metab. 27: 549.

26. Jacobson, E. D. 1967. Pathogenesis of cholera. Gastroenterology. 53: 665 .

27. Scheiffarth, F., L. Zicha, M. Engelhardt, C. Kwiet, and E. Tomat. 1961. Corticoide und neutrale 17-Ketosteroide im Parotisspeichel, Schweiss und Duodenalsaft vor und nach Applikation von Glukocorticoiden. Med. Exp. 5 : 77.

28. Katz, F. H. 1964. Adrenal function during bed rest. Aerospace Med. 35 : 849. 